SIR,-My friend Mr. R. V. Melville's complaint is couched in such disarming and unexpectedly complimentary terms that it is difficult to disagree with his arguments without seeming ungracious. I must, however, point out that to follow von Buch in including the Callovian stage in the Middle Jurassic does not alter "all " established usage and does not draw a " new line ", and that the reason I did not give any "geological reasons" is that I do not think they are really relevant to the question, which is purely one of conventional classification.

In the Swabian Jura the basis of all stratigraphical work since von Buch, down to the present day, has always been his threefold divisions Unterer, Mittlerer, Oberer Jura, or the equivalent Schwarzer, Brauner, Weisser Jura of Quenstedt, which are also the Lias, Dogger, Malm of Oppel. This scheme has priority as a subdivision of the Jurassic (Jura) System, for the four divisions used by Conybeare and Phillips were called the Lias and Lower, Middle and Upper "Oolitic Systems"; the word Jura or Jurassic was not mentioned by them.

In trying to take a world view I was worried by the amount of English stage names we expect our foreign colleagues to adopt. In this matter at least, it seems to me we have no excuse for insisting that the three major subdivisions of the Jurassic System should be based on a modification of Conybeare and Phillips' Lias and three "Oolites". Nor have we any right to complain because the upper boundary of the Middle Jurassic falls in our Oxford Clay, or to expect any such line to " coincide with any formational boundary" in this country. The lower boundary of the Middle Jurassic is almost as bad, falling in Dorset somewhere below the top of the Bridport Sands. From the British point of view nothing could be worse than the upper and lower boundaries of the Jurassic System : one has to be guessed at somewhere in the absolutely continuous PurbeckWealden ; the other avoids by a few feet one of the best breaks imaginable, between the lacustrine Keuper and marine Rhaetic.

If the subdivisions of the Jurassic are to be defined by formations, they can only be the formations of the type area. In a modern classification, however, the primary subdivisions of a system should surely coincide with groups of stages, the smallest units of universal application and based on palaeontological zones.

I have every sympathy with the mapper (and am one myself): but he can only map formations, and has no more need to concern himself with subsystems than with stages. The "practical " arguments against the position of the boundary between the Middle and Upper Jurassic apply equally to that between the Callovian and Oxfordian stages, for the two coincide.

Finally, the fact that (most of) the Bathonian is peculiar and has peculiar ammonite faunas is no more reason for ejecting the Callovian than the Bajocian from the Middle Jurassic.

SedgWick Museum,

W. J. Arkell.

CAMBridoE.

10th September, 1956.

\title{
GEOLOGY IN SCHOOLS
}

SiR,--In his admirable book Geology and Ourselves Dr. F. H. Edmunds expresses the opinion that geology is not really a suitable school subject, but experience in encouraging the introduction of the subject into schools suggests that such lack of interest in it as may exist is due more to the apathy of geologists than to any disadvantages inherent in the subject. In Wales, largely due to the activities of the National Museum of Wales, geology is taught as an examination subject in nearly fifty schools and last year 267 pupils passed the General Certificate of Education examination, about one third of them at the Advanced Level. During the year visits to the Geological Department of the Museum were made by 97 parties from schools $(2,400$ 
pupils) and 31 visits to schools to lecture or conduct field excursions were made in response to invitations. Geological material, comprising small organized exhibits, models, collections of specimens that can be handled, and sets of photographs is circulated by van to about 140 schools all over Wales that ask for it as part of a Schools Service in which all Departments of the Museum share. At any one time more than 600 geological items will be "out" and the demand for them is always greater than the capacity to supply. Many of them are sent out at the request of teachers of geography and the National Museum of Wales is by no means the only one that engages in school activities.

It would seem that geology can be regarded as a suitable school subject provided that it is properly presented, and Dr. Edmunds's suggestion to the contrary is all the more surprising because his own book shows him to have in an unusual degree the capacity to make the study of geology seem worth while.

\section{DePARTMENT OF GEOLOGY, \\ National Museum of Wales, CARDIFF.}

11th September, 1956.

\section{F. J. NORTH.}

\section{REVIEWS}

Geology and Ourselves. By F. H. Edmunds. 256 pp., 50 figs., 12 pls. London (Hutchinson), 1955. Price 21s. net.

Nearly half this book is an introduction to the history, purpose, and methods of geology and geological investigation, necessary because of the difficulty of explaining the practical value of geology to those who as the author puts it are " unversed or but little versed in the subject". Well suited to the needs of the layman the book will appeal to students by reason of the care taken to elucidate matters that are often taken for granted in elementary textbooks.

There are useful chapters on geological surveys and maps, geophysical methods, and the applications of geology in water supply, mining, civil engineering, agriculture and planning. Without entering into textbook details, they give a clear picture of the contributions which geology makes in these fields.

A concluding chapter indicates the potentialities of some branches of geology to interest the amateur and gives first place to the study of the development of scenery. Whilst expressing regret that geology is rarely taught in schools the author concludes that " in present circumstances geology is not really a suitable school subject ". This, he admits, is an apparently defeatist conclusion, but the reasons he gives for arriving at it suggest that it is based upon theoretical considerations and not upon experience.

The diagrams are well devised and clear, but the first, due to a well-known optical illusion, leaves one in doubt as to whether one is looking at a sphere from which a quarter of one hemisphere has been removed, or a similar quarter resting apex upwards within a circle. The half tone illustrations are well chosen in relation to the text, but the printed reproductions of some of them are too contrasty to be either pleasing or easily understood.

F. J. N. 